bioRxiv preprint doi: https://doi.org/10.1101/2022.02 11.480157; this version posted February 142022 . The copyright holder for this preprint (which was not certified by peer review) is the author/funder, who has granted bioRxiv a license to display the preprint in perpetuity. It is made available under aCC-BY 4.0 International license.

\title{
Kinase Suppressor of Ras 2 regulates small-cell lung carcinoma tumor propagating cells
}

Dianna H. Huisman ${ }^{1}$, Danielle E. Frodyma ${ }^{1 \#}$, Robert A. Svoboda, Heidi M. Vieira ${ }^{1}$, Deepan Chatterjee ${ }^{1}$, Sydney Skupa $^{1}$, James W. Askew ${ }^{1}$, Kurt W. Fisher ${ }^{2}$, Michael S. Kareta ${ }^{3}$, Trudy G. Oliver ${ }^{4}$, Robert E. Lewis ${ }^{1 *}$

${ }^{1}$ Eppley Institute, Fred \& Pamela Buffett Cancer Center, University of Nebraska Medical Center, Omaha, NE 68198, USA.

2Department of Pathology and Microbiology, University of Nebraska Medical Center, Omaha, NE 68198, USA.

${ }^{3}$ Cancer Biology and Immunotherapies Group, Sanford Research, Sioux Falls, South Dakota.

${ }^{4}$ Huntsman Cancer Institute, University of Utah, Salt Lake City, UT, USA.

\#Current address: Methodist Physicians Clinic, Omaha NE

*Correspondence: rlewis@unmc.edu 


\section{Abstract}

Tumor propagating cells (TPCs) make up a small proportion of tumor cells responsible for self-renewal and long-term propagation of small-cell lung carcinoma (SCLC) tumors. Here, we show that Kinase Suppressor of Ras 2 (KSR2) is an important regulator of the self-renewing and clonogenic properties of SCLC cells. KSR2 is a molecular scaffold which promotes Raf/MEK/ERK signaling and AMPK signaling in SCLC. KSR2 is

preferentially expressed in the ASCL1 subtype of SCLC tumors as well as the pulmonary neuroendocrine cells from which the SCLC tumors arise. The expression of KSR2 in SCLC and pulmonary neuroendocrine cells was previously unrecognized and serves as a novel model for understanding the role of KSR2-dependent signaling in normal and malignant tissues. Disruption of KSR2 in SCLC-A cell lines significantly reduces colony forming ability of TPCs in vitro and tumor initiating capacity in vivo. These data indicate that the expression of KSR2 is an essential driver of SCLC-A tumor propagating cell function, and therefore may play a role in SCLC tumor initiation. These findings shed light on a key distinct protein responsible for regulation in ASCL1 subtype SCLC tumors, and a potential subtype specific therapeutic target. 
Introduction

Small-cell lung carcinoma (SCLC) affects current and former heavy smokers, accounting for $13 \%$ of all lung cancers $^{1}$. There have been few improvements in SCLC detection, treatment, and survival in the past 30 years, leading to its classification as a recalcitrant cancer in $2012^{1}$. The five-year relative survival rates for SCLC patients with localized, regional, and distant disease are $27 \%, 16 \%$, and $3 \%$, respectively (American Cancer Society, 2021). Currently, SCLC tumors are treated with first line therapy (cisplatin or carboplatin plus antiPDL1 antibody, atezolizumab), second (topotecan), and third line (PD1 antagonist, nivolumab) therapies. Although SCLC tumors are responsive to therapy initially, residual disease quickly develops resistance leading to the low five-year survival ${ }^{2}$. Substantial efforts have been made to characterize SCLC tumors and identify targets that may be selectively toxic to tumor cells while preserving normal lung tissue ${ }^{3-7}$. Rigorous and innovative basic science using state-of-the-art genetically engineered mouse models (GEMM), and an extensive set of cell lines have led to key discoveries regarding the cells-of-origin and the common recurring mutations that underlie SCLC ${ }^{8-15}$. These discoveries have yielded comprehensive genomic profiles and a durable classification of SCLC subtypes based on the differential expression of four key transcription factors, ASCL1 (SCLC-A), NeuroD1 (SCLC-N), Pou2F3 (SCLC-P) and Yap1 (SCLC-Y) $)^{6,12}$.

Lineage tracing and single cell RNA sequencing (scRNA-seq) in genetically modified mice showed that a rare PNEC subpopulation, NE ${ }^{\text {stem }}$ cells, actively responds to lung injury of the epithelia by expanding, migrating, and undergoing Notch-dependent transit amplification to regenerate the lost epithelium ${ }^{16}$. This effort additionally identified NE ${ }^{\text {stem }}$ as a cell-of-origin for SCLC following TP53, Rb and Notch mutation causing constitutive activation of stem cell renewal and altered deprogramming ${ }^{16}$. SCLC tumors have a small population of tumor propagating cells (TPCs) essential to the initiation, long-term propagation, and metastatic capacity of the tumor, while bulk non-TPC population are highly proliferative but incapable of establishing tumors in vivo ${ }^{17}$. TPCs have been implicated in initiation and growth of SCLC as well as therapy resistance ${ }^{18-24}$. Tumor propagating cells are also implicated in epithelial-to-mesenchymal transition (EMT) and metastasis ${ }^{24}$. Their slower cycling and self-renewing ability enhance DNA repair, rendering these cells resistant to DNA damagedependent chemo and radiation therapy ${ }^{20,21,24,25}$. Thus, SCLC TPCs offer a unique population within which to search for new targets, which in combination with current standard-of-care therapies may yield a durable and effective strategy for therapy.

Kinase Suppressor of Ras 2 (KSR2) is a molecular scaffold for Raf/MEK/ERK signaling, that also interacts with AMPK. AMPK is a critical intermediate of KSR2-dependent signals controlling cell and organismal metabolism ${ }^{26,27}$. KSR2 is abundantly expressed in the brain, and disruption reduces body temperature, promotes cold intolerance, impairs glucose homeostasis, elevates fasting insulin and free fatty acid levels in the blood, and causes obesity ${ }^{27}$. Interestingly, ChIP-seq analysis of human ASCL1 subtype SCLC cell lines revealed KSR2 as a transcriptional target ${ }^{28,29}$. KSR2 was identified as one of 24 druggable and overexpressed target genes of ASCL1 identified by Chip-seq, providing rationale for studying the role of KSR2 in ASCL1 subtype SCLC ${ }^{30}$. Our work reveals that KSR2 is expressed in PNECs as well as SCLC-A tumors and cell lines, although its role has not previously been determined. Expression of KSR2 promotes clonogenicity of SCLC-A TPCs and their tumor initiating capacity in vitro and in vivo. This result defines a novel mechanism of tumor initiation in SCLC-A and a potential therapeutic vulnerability.

\section{Results}

Pulmonary neuroendocrine cells and ASCL1 subtype SCLC tumor express KSR2. ASCL1 subtype (SCLC-A) tumors can arise from PNECs ${ }^{16,28,30,31}$. PNECs are heterogeneous, including a small subpopulation termed $\mathrm{NE}^{\text {stem }}$ cells that respond to lung injury of the epithelia by expanding, migrating, and undergoing Notchdependent transit amplification to regenerate the lost epithelium ${ }^{16}$. Although KSR2 mRNA is not detectable in normal epithelial lung tissue (Fig. 1A), it is present in PNECs (Fig. 1B). SCLC tumors may arise from PNECs following TP53, $\mathrm{Rb}$, and Notch mutations causing constitutive activation of stem cell renewal and altered deprogramming ${ }^{16}$. Analysis of human SCLC tumors in collaboration with Dr. Trudy Oliver (Huntsman Cancer Center, U. Utah) showed that ASCL1-high and MYC-low tumors ${ }^{12}$ preferentially express KSR2 mRNA (Fig. 1C). Analysis of KSR2 mRNA by subtype reveals that KSR2 is highly expressed in the ASCL1 subtype of SCLC (SCLC-A), but has varying expression in NeuroD1, POU2F3, and Yap1 subtypes (Fig. 1D). By western blot analysis, SCLC-A cell lines show high expression of KSR2, while KSR2 is not detectable in the NeuroD1 subtype (Fig. 1E, 1F). 
Depletion of Kinase Suppressor of Ras 2 reduces SCLC clonogenicity and self-renewal. A small population of tumor-initiating cells termed "tumor propagating cells" (TPCs) ${ }^{17}$ are responsible for the long-term propagation and survival of the tumor, as well as therapy resistance ${ }^{17}$. These cells are essential for tumor initiation and metastasis and are characterized by high expression of CD24 and EpCAM, and, somewhat surprisingly, low expression of CD44 ${ }^{17}$, which is often associated with stem cells. A key property of TPCs is their ability to both self-renew and differentiate into the highly proliferative non-TPC population of the tumor. Therefore, identifying the vulnerabilities specific to TPCs will lead to better understanding of mechanisms to perturb SCLC tumor-initiating cells. Transplantation assays show that TPCs are a minor but highly tumorigenic subpopulation of SCLC cells. This population can be analyzed by isolating single cells and measuring colony forming activity, which is an index of clonogenicity and self-renewal ${ }^{17,32}$. Mouse SCLC cell lines KP1 and KP3 were derived from spontaneous GEMM of SCLC with knockout of Rb, p53 (KP1) and Rb, p53 and p130 (KP3), replicate the ASCL1 subtype of SCLC tumors ${ }^{6,10}$. KP1 and KP3 cells can be stained for TPC markers CD24 ${ }^{\text {high }} C D 44^{\text {low }} E p C A M^{\text {high }}$ and isolated by fluorescence-activated cell sorting (FACS) (Fig. 2A). KP1 and KP3 cells expressing one of three dox-inducible shRNAs targeting KSR2 (sh5, sh6, sh7) were treated with or without doxycycline (Fig. 2B). Following downregulation of KSR2 expression, the cells were stained for TPC markers CD24 ${ }^{\text {high }} C D 44^{\text {low }}{ }^{2}$ PCAM ${ }^{\text {high }}$, isolated by FACS and plated as single cells in 96-well plates to be analyzed for colony formation by CellTiter-Glo®. The proportion of TPCs was significantly reduced with Doxinduced RNAi of KSR2 (Fig. 2C). Robust colony formation, a measure of self-renewing capability of an individual cell ${ }^{33-35}$, was observed in KP3 control TPCs. Viability was reduced by $91 \%, 58 \%$, and $45 \%$ with KSR2 RNAi by sh5, 6, and 7, respectively, which is proportional to their effectiveness at targeting KSR2 (Fig. 2B, D). In KP1 cells, colony formation was assessed with or without Dox-induced RNAi by the most effective hairpin sh5 after TPC isolation, which significantly inhibited colony formation (Fig. 2B, E). These data demonstrate that KSR2 is a significant contributor to the clonogenic and self-renewing properties of SCLC TPCs.

KSR2 regulates ERK and AMPK in SCLC cells. To confirm on target effects of our inducible shRNA system for KSR2 knockdown, a construct containing wildtype KSR2 mutated to be resistant to binding hairpin sh5 (KSR2-R) was expressed in KP1 sh5 cells (Fig. 3A). Rescue of KSR2 expression restored colony formation to wildtype levels in KP1 sh5 cells confirming on target effects of hairpin sh5 (Fig. 3B). The Raf/MEK/ERK pathway and AMPK interact with, and are modulated by KSR2 in human and mouse cell lines ${ }^{27,36}$. Knockdown of KSR2 reduces activation of ERK and AMPK signaling in human (Fig. 3C) and murine (Fig. 3D) SCLC cell lines. These data show that KSR2 signaling is preserved in SCLC, suggesting that KSR2-dependent AMPK and/or ERK signaling may contribute to SCLC formation or maintenance.

KSR2 disruption inhibits the tumor initiating capacity of murine SCLC cells in vivo. Extreme limiting dilution analysis (ELDA) is a software application optimized for estimating the stem cell frequency from limiting dilution analysis ${ }^{37}$. In vivo ELDA determines the stem cell frequency within the bulk tumor cell population from the frequency of tumor-positive and tumor-negative injections at a variety of transplant doses. The effect of KSR2 disruption in vivo was tested using ELDA ${ }^{17}$. Dox-inducible shRNA targeted KP1 cells were injected with successive dilutions into NOD-Prkd ${ }^{c e m 26 C d 52} / / 2 \mathrm{rg}^{\mathrm{em} 26 \mathrm{Cd} 22} / \mathrm{NjuCrl}$ (NCG) mice, and the mice were provided drinking water with sucrose, or sucrose plus doxycycline $(2 \mathrm{mg} / \mathrm{kg})$. Tumors were monitored until one tumor reached $1 \mathrm{~cm}^{2}$ and then all mice were sacrificed. ELDA was performed by scoring all tumors in the control group as " 1 " and all tumors retaining knockdown in the doxycycline treated group as " 1 ". The absence of tumor formation was scored as "0". KSR2 disruption reduced frequency of TPCs 10-fold, from 1/255 control KP1 cells to $1 / 2530 \mathrm{KP} 1$ cells with KSR2 KD (Fig. 4, Table 1). These data indicate that KSR2 is a critical effector of selfrenewal and clonogenicity of SCLC tumor propagating cells in vivo.

\section{Discussion}

Our data have identified Kinase Suppressor of Ras 2 as a novel regulator of tumor initiation in ASCL1 subtype SCLC cells, and therefore a potential subtype specific therapeutic vulnerability. Due to modest improvement in early detection, therapeutic options, or survival in the last 30 years, SCLC was categorized as a recalcitrant cancer in $2012^{38}$. Rigorous molecular characterization of SCLC tumors has yielded four recognized subtypes of SCLC based on expression of transcription factors ASCL1, NeuroD1, YAP1, and POU2F3 ${ }^{6,8,12,13}$. Approximately $69 \%$ of SCLC tumors are ASCL1-dominant while $17 \%$ are NeuroD1-dominant, and $14 \%$ are 
double negative for ASCL1 and NeuroD1 ${ }^{39}$. Currently, all small-cell lung carcinomas are treated with the same standard of care despite recent evidence that Myc-driven NeuroD1 tumors are responsive to distinct therapies from ASCL1 subtype tumors ${ }^{40,41}$. Our work shows that KSR2 is a novel regulator of SCLC-A TPC clonogenicity, and a potential subtype specific therapeutic target.

We have demonstrated the ability of KSR2 to regulate AMPK and ERK activation in SCLC cell lines similar to its previously defined role in mouse tissues ${ }^{27,42}$. Previous studies tested the efficacy of targeting Raf/MEK/ERK signaling in SCLC have had mixed results. Treatment with ERK inhibitor was found not to induce apoptosis in human SCLC-A cell lines $\mathrm{H} 209$ and $\mathrm{H}_{69}{ }^{43}$, or reduce proliferation in murine SCLC-A cell line KP1 (data not shown). In contrast to these data, ARHGEF19 disruption, which leads to reduced Raf/MEK/ERK signaling significantly reduced SCLC-A cell line proliferation in vitro and in in vivo tumor xenografts ${ }^{44}$. Activation of Raf/MEK/ERK by endoplasmic reticulum (ER) stress has been reported to promote SCLC cell survival| ${ }^{45}$. It has been proposed that Raf/MEK/ERK signaling may play an essential role in promoting metastasis of SCLC tumors $^{46}$. CXCL12 has been shown to induce ERK activation in SCLC cells, which was correlated with increased invasion through extracellular matrix ${ }^{47}$. Although the role of ERK signaling in SCLCs is incompletely understood, it has been implicated in cell proliferation, differentiation, survival, and drug resistance ${ }^{48}$ therefore, $^{4}$ evaluating its potential role in regulating tumor initiation is necessary to understand the implications of targeting ERK signaling in SCLC tumors. Our study shows that KSR2, a molecular scaffold for the MAPK signaling pathway, is an important regulator of tumor initiating capacity. The relative contribution of KSR2-dependent AMPK and ERK activation to SCLC clonogenicity and tumor initiation has not yet been defined, and future studies will evaluate the KSR2-dependent mechanisms of supporting the function of the tumor-propagating cell population.

Kinase Suppressor of Ras 2 (KSR2) interacts with effectors of the Raf/MEK/ERK signaling cascade, calcineurin, and AMPK ${ }^{27,36,42}$. Through these interactions, KSR2 promotes phosphorylation of AMPK and ERK, and we have shown that disrupting KSR2 reduces clonogenicity of SCLC tumor-propagating cells. Previous studies in our lab showed that low and high levels of exogenous KSR2 promote proliferation of mouse embryonic fibroblasts (MEFs) in an ERK independent manner, and that high levels of KSR2 block ERK activation in response to PDGF treatment ${ }^{26}$. These data suggest that the role of KSR2 in promoting SCLC clonogenicity may be multifaceted. By targeting KSR2 rather than ERK or AMPK individually, we may see additional therapeutic benefit. KSR2 disruption coordinately reduces Raf/MEK/ERK signaling and AMPK signaling. Our future work aims to detail the relative contribution of KSR2-dependent Raf/MEK/ERK signaling and AMPK signaling in promoting self-renewal and clonogenicity in SCLC-A tumors.

We show that KSR2 is preferentially expressed in the ASCL1-subtype of SCLC tumors as well as their cell of origin, PNECs. In the SCLC-A tumors derived from PNECs, ASCL1 is indispensable for tumor formation ${ }^{13}$. ChIP-seq analysis of ASCL1 subtype SCLCs revealed KSR2 as a transcriptional target ${ }^{28,29}$. KSR2 was identified as one of 24 druggable and overexpressed target genes of ASCL1 identified by Chip-seq ${ }^{30}$. Interestingly, SCLC-A tumors can be converted to non-NE subtype tumors including NeuroD1 and YAP1 by overexpressing $\mathrm{Myc}^{49}$. The signaling pathways involved in Myc-driven tumor evolution remain largely undefined and the potential role of KSR2 in driving or maintaining the ASCL1 subtype is yet to be determined. Disruption of KSR2 expression in SCLC-A cell lines significantly reduce the proportion of tumor-propagating cells (TPCs), and the ability of SCLC TPCs to form colonies in vitro. Disruption of KSR2 reduces the TPC frequency in vivo, reducing tumor formation 10-fold. We demonstrated that KSR2 disruption reduces Raf/MEK/ERK signaling and AMPK activation, both of which potentially contribute to the effects on clonogenicity. Further characterization of the mechanisms through which KSR2 is promoting clonogenicity, and tumor initiation should reveal novel understanding of the regulation of tumor initiation in ASCL1 subtype SCLC tumors.

\section{Materials and Methods}

\section{Cell culture}

Murine small-cell lung carcinoma cell lines KP1 and KP3 were a gift from J. Sage (Stanford University). Human small-cell lung carcinoma cell lines $\mathrm{H} 209$ and $\mathrm{H} 1963$ were a gift of John Minna (UT Southwestern). The cells were cultured in RPMI 1640 medium containing $10 \%$ fetal bovine serum (FBS) and grown at $37^{\circ} \mathrm{C}$ with ambient 
$\mathrm{O}_{2}$ and $5 \% \mathrm{CO}_{2}$. Cells were routinely tested for mycoplasma. No further authentication of cell lines was performed by the authors.

\section{Generation of KSR2 shRNA knockdown cell lines}

Individual SMARTvector human inducible lentiviral shRNAs targeting KSR2 expressed in piSMART hEF1a/TurboGFP vector were stably transfected into KP1, KP3, and H209 SCLC cell lines with PEI. Cells were selected for expression of the shRNAs using $0.25 \mathrm{ug} / \mathrm{mL}$ of puromycin. 48 hours after doxycycline induction, cells were selected again by flow cytometry sorting for GFP+ cells. Knockdown of KSR2 was confirmed by western blot. KSR2 cDNA (MSCV KSR2 IRES GFP) was made resistant to binding of hairpin sh5 by introducing three point mutations in the binding region. Point mutations were introduced using the QuikChange Lightning Site Directed Mutagenesis Kit (Agilent \#210518) according to the manufacturer's protocol. MSCV KSR2 IRES GFP resistant to binding hairpin sh5 (sh5RKSR2) was transfected into HEK-293T cells using trans-lentiviral packing system (ThermoFisher Scientific). The virus was collected 48 hours post transfection and used to infect KP1 sh5 cells with $8 \mathrm{ug} / \mathrm{mL}$ Polybrene for 72 hours. KP1 sh5 cells expressing the sh5RKSR2 construct were selected for using flow cytometry sorting YFP+ cells. Presence of the sh5RKSR2 expression after doxycycline induced downregulation on endogenous KSR2 was confirmed via western blotting.

\section{Cell lysis and western blot analysis}

Whole cell lysate was extracted in radioimmunoprecipitation assay (RIPA) buffer containing $50 \mathrm{mM} \mathrm{Tris-} \mathrm{HCl}$, $1 \% \mathrm{NP}-40,0.5 \% \mathrm{Na}$ deoxycholate, $0.1 \% \mathrm{Na}$ dodecyl sulfate, $150 \mathrm{mM} \mathrm{NaCl}, 2 \mathrm{mM}$ EDTA, $2 \mathrm{mM}$ EGTA, and 1 $X$ protease and phosphatase inhibitors aprotinin $(0.5 \mathrm{U} / \mathrm{mL})$, leupeptin $(20 \mathrm{mM})$, and $\mathrm{NA}_{3} \mathrm{VO}_{4}(0.5 \mathrm{mM})$. The estimation of protein concentration was done using BCA protein assay (Promega \#PI-23222, PI-23224). Samples were diluted using $1 \mathrm{X}$ sample buffer (4 X stock, LI-COR \#928-40004) with $100 \mathrm{mM}$ dithiothreitol (DTT) (10 X stock, $1 \mathrm{mM}$, Sigma \#D9779-5G). The protein was separated using 8-12\% SDS-PAGE and transferred to nitrocellulose membrane. The membrane was blocked with Odyssey TBS blocking buffer (LICOR-Biosciences \#927-50003) for $45 \mathrm{~min}$ at room temperature, then incubated with primary antibodies (Key Resources Table) at least overnight at $4^{\circ} \mathrm{C}$. IRDye $800 \mathrm{CW}$ and 680RD secondary antibodies (LI-COR Biosciences \# 926-32211, \# 926-68072) were diluted 1:10,000 in 0.1\% TBS-Tween and imaged on the Odyssey Classic Scanner (LI-COR Biosciences).

\section{Analysis of KSR2 expression in normal tissues}

GTEx portal was used to display the relative expression of KSR2 mRNA (TPM) in brain-cortex and lung tissue. Neuroendocrine specific reporter, Chga-GFP was used to identify PNECs. GFP+ neuroendocrine cells from 3 mouse lungs were isolated by flow cytometry. qPCR was performed to measure mRNA expression of Ksr2, Crgp, Chga, Syp, and Spc in GFP+ neuroendocrine cells and GFP- lung epithelial cells.

\section{SCLC sequencing analysis}

RNA sequencing data from human primary tumor samples ${ }^{12}$ was analyzed for KSR2 expression based on high and low ASCL1 expression or high and low Myc expression (with Trudy Oliver, Huntsman Cancer Institute). RNA sequencing data of human SCLC cell lines (CCLE, Broad Institute MIT) was segregated by SCLC subtype and analyzed for KSR2 mRNA levels.

\section{Fluorescence Activated Cell Sorting}

SCLC cell lines were incubated 20 minutes on ice in PBS with DAPI (3uM), PE-CD24 (1:400) PE-Cy7-CD44 (1:300) and APC-EpCAM (1:100). Cells were resuspended in PBS and flow cytometry of SCLC cell lines was performed using a 100um nozzle on a BD FACSAria II using FACSDiva software. Debris were excluded by gating on forward scatter area versus side scatter area. Doublet were excluded by gating on forward scatter area versus side scatter height. Viable cells were identified by exclusion of DAPI stained cells. CD24 ${ }^{\text {high }} \mathrm{CD} 44^{\text {low }}$ cells were included by sequential gating followed by EpCAM ${ }^{\text {high }}$ TPCs. Compensation was performed using single stain and fluorescence- one (FMO) controls. Positive gates were set based on the negative unstained sample. Data were analyzed using FlowJo software.

\section{Colony Formation Assay}

For colony formation assays, SCLC cells were dissociated by gentle pipetting. Live TPCs were sorted using a $100 \mu \mathrm{m}$ nozzle on a BD FACSAria II. TPCs were sorted individually into 96 well plates filled with regular media 
$(200 \mu \mathrm{l} /$ well $)$ containing DMSO or doxycycline (DOX) $(1 \mathrm{ug} / \mathrm{mL}) .50 \mathrm{uL}$ fresh media with or without DOX was added to the wells every 10 days. Three weeks later, colony numbers were assessed using CellTiter-Glo 2.0 reagent (Promega \#G9242) and luminescence was measured (POLARstar Optima plate reader) according to the manufacturer's protocol.

\section{In vivo Extreme Limiting Dilution Analysis}

The viable cell number was assessed by replicate cell counts on a hemocytometer using Trypan Blue exclusion. Viable cell number was used to derive a titration of cell numbers for implantation. Cells were diluted

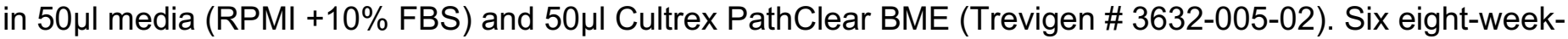
old NCG mice were injected subcutaneously into the shoulders and flanks. 3 replicates for each dilution were used. Mice were provided drinking water with sucrose, or sucrose plus doxycycline $(2 \mathrm{mg} / \mathrm{kg})$. Injection sites were palpated biweekly to monitor for tumor growth and all mice were sacrificed when any one tumor reached $1 \mathrm{~cm}$. Tumors that formed were scored as 1 and the absence of tumor formation was scored as 0 for the extreme limiting dilution analysis (ELDA). Tumors that formed were analyzed for expression of KSR2 by western blot and tumors in the doxycycline treated group which did not maintain knockdown were scored as 0 . ELDA software was used to estimate TPC frequency for control and doxycycline treated groups. 


\section{Bibliography}

1. Gazdar, A.F., Bunn, P.A. \& Minna, J.D. Small-cell lung cancer: what we know, what we need to know and the path forward. Nat Rev Cancer 17, 765 (2017).

2. Gay, C.M. et al. Patterns of transcription factor programs and immune pathway activation define four major subtypes of SCLC with distinct therapeutic vulnerabilities. Cancer Cell 39, 346-360 e347 (2021).

3. Byers, L.A. et al. Proteomic profiling identifies dysregulated pathways in small cell lung cancer and novel therapeutic targets including PARP1. Cancer Discov 2, 798-811 (2012).

4. Gazdar, A.F., Bunn, P.A. \& Minna, J.D. Small-cell lung cancer: what we know, what we need to know and the path forward. Nat Rev Cancer 17, 725-737 (2017).

5. Gazdar, A.F., Carney, D.N., Nau, M.M. \& Minna, J.D. Characterization of variant subclasses of cell lines derived from small cell lung cancer having distinctive biochemical, morphological, and growth properties. Cancer Res 45, 2924-2930 (1985).

6. George, J. et al. Comprehensive genomic profiles of small cell lung cancer. Nature 524, 47-53 (2015).

7. McFadden, David G. et al. Genetic and Clonal Dissection of Murine Small Cell Lung Carcinoma Progression by Genome Sequencing. Cell 156, 1298-1311 (2014).

8. Sutherland, Kate D. et al. Cell of Origin of Small Cell Lung Cancer: Inactivation of Trp53 and Rb1 in Distinct Cell Types of Adult Mouse Lung. Cancer Cell 19, 754-764 (2011).

9. Yang, D. et al. Intertumoral Heterogeneity in SCLC Is Influenced by the Cell Type of Origin. Cancer Discov 8, 1316-1331 (2018).

10. Park, K.S. et al. Characterization of the cell of origin for small cell lung cancer. Cell Cycle 10, 28062815 (2011).

11. Schaffer, B.E. et al. Loss of p130 accelerates tumor development in a mouse model for human smallcell lung carcinoma. Cancer Res 70, 3877-3883 (2010).

12. Rudin, C.M. et al. Molecular subtypes of small cell lung cancer: a synthesis of human and mouse model data. Nat Rev Cancer 19, 289-297 (2019).

13. Borromeo, M.D. et al. ASCL1 and NEUROD1 Reveal Heterogeneity in Pulmonary Neuroendocrine Tumors and Regulate Distinct Genetic Programs. Cell Rep 16, 1259-1272 (2016).

14. Gazdar, A.F. \& Minna, J.D. Cell lines as an investigational tool for the study of biology of small cell lung cancer. Eur J Cancer Clin Oncol 22, 909-911 (1986).

15. Carney, D.N. et al. Establishment and identification of small cell lung cancer cell lines having classic and variant features. Cancer Res 45, 2913-2923 (1985).

16. Ouadah, Y. et al. Rare Pulmonary Neuroendocrine Cells Are Stem Cells Regulated by Rb, p53, and Notch. Cell 179, 403-416 e423 (2019).

17. Jahchan, N.S. et al. Identification and Targeting of Long-Term Tumor-Propagating Cells in Small Cell Lung Cancer. Cell Rep 16, 644-656 (2016).

18. Stewart, C.A. \& Byers, L.A. Altering the Course of Small Cell Lung Cancer: Targeting Cancer Stem Cells via LSD1 Inhibition. Cancer Cell 28, 4-6 (2015).

19. Sancho, P., Barneda, D. \& Heeschen, C. Hallmarks of cancer stem cell metabolism. Br J Cancer 114, 1305-1312 (2016).

20. Ailles, L.E. \& Weissman, I.L. Cancer stem cells in solid tumors. Curr Opin Biotechnol 18, 460-466 (2007).

21. Borah, A., Raveendran, S., Rochani, A., Maekawa, T. \& Kumar, D.S. Targeting self-renewal pathways in cancer stem cells: clinical implications for cancer therapy. Oncogenesis 4, e177 (2015).

22. Codony-Servat, J., Verlicchi, A. \& Rosell, R. Cancer stem cells in small cell lung cancer. Trans/ Lung Cancer Res 5, 16-25 (2016).

23. Hu, J. et al. Cancer stem cell self-renewal as a therapeutic target in human oral cancer. Oncogene (2019).

24. Yang, F., Xu, J., Tang, L. \& Guan, X. Breast cancer stem cell: the roles and therapeutic implications. Cell Mol Life Sci 74, 951-966 (2017).

25. Geradts, J. et al. Human lung cancer cell lines exhibit resistance to retinoic acid treatment. Cell Growth Differ 4, 799-809 (1993).

26. Fernandez, M.R., Henry, M.D. \& Lewis, R.E. Kinase suppressor of Ras 2 (KSR2) regulates tumor cell transformation via AMPK. Mol Cell Biol 32, 3718-3731 (2012).

27. Costanzo-Garvey, D.L. et al. KSR2 is an essential regulator of AMP kinase, energy expenditure, and insulin sensitivity. Cell Metab 10, 366-378 (2009). 
28. Borges, M. et al. An achaete-scute homologue essential for neuroendocrine differentiation in the lung. Nature 386, 852-855 (1997).

29. Kim, E.J., Ables, J.L., Dickel, L.K., Eisch, A.J. \& Johnson, J.E. Ascl1 (Mash1) defines cells with longterm neurogenic potential in subgranular and subventricular zones in adult mouse brain. PLoS One 6 , e18472 (2011).

30. Augustyn, A. et al. ASCL1 is a lineage oncogene providing therapeutic targets for high-grade neuroendocrine lung cancers. Proc Natl Acad Sci U S A 111, 14788-14793 (2014).

31. Sutherland, K.D. et al. Cell of origin of small cell lung cancer: inactivation of Trp53 and Rb1 in distinct cell types of adult mouse lung. Cancer Cell 19, 754-764 (2011).

32. Johnson, S., Chen, H. \& Lo, P.K. In vitro Tumorsphere Formation Assays. Bio Protoc 3 (2013).

33. Gou, S. et al. Establishment of clonal colony-forming assay for propagation of pancreatic cancer cells with stem cell properties. Pancreas 34, 429-435 (2007).

34. Rajendran, V. \& Jain, M.V. In Vitro Tumorigenic Assay: Colony Forming Assay for Cancer Stem Cells. Methods Mol Biol 1692, 89-95 (2018).

35. Chang, K.J., Yin, J.Z., Huang, H., Li, B. \& Yang, M.H. Arsenic trioxide inhibits the growth of cancer stem cells derived from small cell lung cancer by downregulating stem cell-maintenance factors and inducing apoptosis via the Hedgehog signaling blockade. Transl Lung Cancer Res 9, 1379-1396 (2020).

36. Dougherty, M.K. et al. KSR2 is a calcineurin substrate that promotes ERK cascade activation in response to calcium signals. Mol Cell 34, 652-662 (2009).

37. Hu, Y. \& Smyth, G.K. ELDA: extreme limiting dilution analysis for comparing depleted and enriched populations in stem cell and other assays. J Immunol Methods 347, 70-78 (2009).

38. Gazdar, A.F., Bunn, P.A. \& Minna, J.D. Small-cell lung cancer: what we know, what we need to know and the path forward. Nature Reviews Cancer 17, 725 (2017).

39. Baine, M.K. et al. SCLC Subtypes Defined by ASCL1, NEUROD1, POU2F3, and YAP1: A Comprehensive Immunohistochemical and Histopathologic Characterization. J Thorac Oncol 15, 18231835 (2020).

40. Chalishazar, M.D. et al. MYC-Driven Small-Cell Lung Cancer is Metabolically Distinct and Vulnerable to Arginine Depletion. Clin Cancer Res 25, 5107-5121 (2019).

41. Mollaoglu, G. et al. MYC Drives Progression of Small Cell Lung Cancer to a Variant Neuroendocrine Subtype with Vulnerability to Aurora Kinase Inhibition. Cancer Cell 31, 270-285 (2017).

42. Guo, L. et al. Kinase Suppressor of Ras 2 (KSR2) expression in the brain regulates energy balance and glucose homeostasis. Mol Metab 6, 194-205 (2017).

43. Tsurutani, J., West, K.A., Sayyah, J., Gills, J.J. \& Dennis, P.A. Inhibition of the phosphatidylinositol 3kinase/Akt/mammalian target of rapamycin pathway but not the MEK/ERK pathway attenuates lamininmediated small cell lung cancer cellular survival and resistance to imatinib mesylate or chemotherapy. Cancer Res 65, 8423-8432 (2005).

44. Wang, Z. et al. ARHGEF19 regulates MAPK/ERK signaling and promotes the progression of small cell lung cancer. Biochem Biophys Res Commun 533, 792-799 (2020).

45. Liu, Y. et al. Resistance to BH3 mimetic S1 in SCLC cells that up-regulate and phosphorylate Bcl-2 through ERK1/2. Br J Pharmacol 169, 1612-1623 (2013).

46. Cristea, S. \& Sage, J. Is the Canonical RAF/MEK/ERK Signaling Pathway a Therapeutic Target in SCLC? J Thorac Oncol 11, 1233-1241 (2016).

47. Burger, M. et al. Functional expression of CXCR4 (CD184) on small-cell lung cancer cells mediates migration, integrin activation, and adhesion to stromal cells. Oncogene 22, 8093-8101 (2003).

48. Barbosa, R., Acevedo, L.A. \& Marmorstein, R. The MEK/ERK Network as a Therapeutic Target in Human Cancer. Mol Cancer Res 19, 361-374 (2021).

49. Ireland, A.S. et al. MYC Drives Temporal Evolution of Small Cell Lung Cancer Subtypes by Reprogramming Neuroendocrine Fate. Cancer Cell 38, 60-78 e12 (2020). 


\section{Figure Legends}

Fig. 1. A) KSR2 mRNA in brain tissue and lung epithelial tissue (GTEx Portal). B) GFP ${ }^{+}$cells isolated from the lungs of mice expressing GFP from the promoter for the neuroendocrine (NE)-specific Crgp. mRNA expression of KSR2 (left), neuroendocrine markers (Chga, Syp) (middle), and lung epithelial marker surfactant protein $\mathrm{C}$ (SPC) (right). C) KSR2 expression in human ASCL-1 subtype SCLC tumors (left) and tumors with elevated Myc expression (right) from RNA-seq analysis of human SCLC tumors. ${ }^{* *}, p<0.01$ D) KSR2 RNAseq (DepMap) in SCLC segregated by subtype. ${ }^{*} p=0.03 ;{ }^{* *} p<0.004 ;{ }^{* * * *} p<0.0001$. E) KSR2 expression, with Actin loading control, in western blots of ASCL1 subtype SCLC cell lines and non-transformed human bronchial epithelial cells (HBEC). F) KSR2 expression, with Actin loading control, in western blots of ASCL1(A) or, NeuroD1 (N) subtypes SCLC lines and non-transformed human bronchial epithelial cells (HBEC).

Fig. 2. A) FACS of KP1 cells for CD24 ${ }^{\text {high }} \mathrm{CD}^{\text {low }}{ }^{\text {(left) and }} \mathrm{EPCAM}^{\text {high }}$ (right). B) Dox-inducible RNAi of KSR2 in KP1 cells from SCLC GEMM. NTC, non-targeting control. Actin, loading control. C) Percent TPCs detectable in control or KSR2-targeted (sh5) KP1 cells. Clonogenicity of Dox-treated KP3 (D) and KP1 (E) SCLC TPCs with and without the indicated shRNAs targeting KSR2. Colony viability was measured by CellTiter-Glo. ${ }^{* * * *}$, $\mathrm{p}<0.0001, \mathrm{n}=3$.

Fig. 3. A) KSR2 cDNA resistant to the sh5 shRNA (KSR2-R) or the empty expression vector were introduced into KP1 cells expressing the Dox-inducible sh5 shRNA. HDAC2, loading control. B) Clonogenicity of KP1 SCLC TPC colonies within wildtype (WT), dox-induced RNAi of KSR2 (sh5) and dox-induced RNAi of KSR2 + KSR2-R. Colony viability was measured by CellTiter-Glo. ${ }^{* * *}, p<0.0001$. C-D) Dox-inducible RNAi of KSR2 in human SCLC (H209) (C) and KP1 cells (D) from SCLC GEMM. Actin, loading control. HDAC2, loading control.

Fig. 4. Quantification (left) and raw data (right) of in vivo extreme limiting dilution analysis of KP1 cells without and with Dox-induced RNAi of KSR2. ${ }^{* *}, p=0.00698$. 
bioRxiv preprint doi: https://doi. org/10.1101/2022.02.11.480157; this version posted February 14,2022 . The copyright holder for this preprint (which was not certified by peer review) is the author/funder, who has granted bioRxiv a license to display the preprint in perpetuity. It is made available under aCC-BY 4.0 International license.

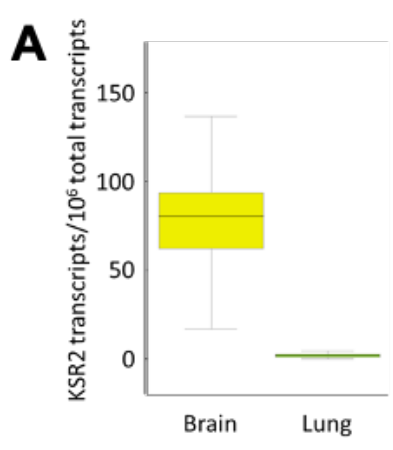

D

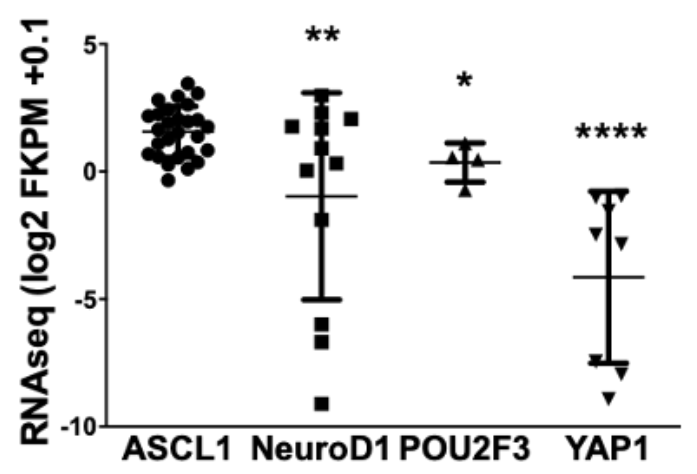

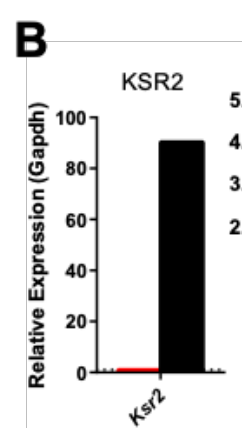

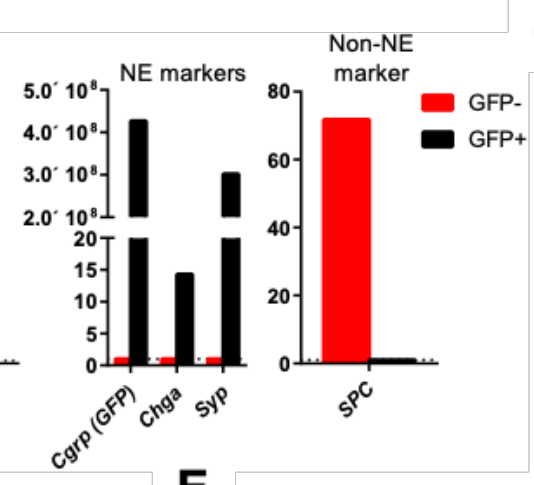

E

C Human SCLC Tumors ( $n=81)$
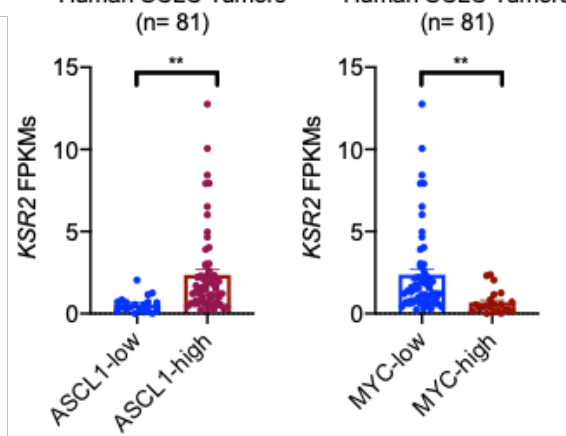

Fig. 1

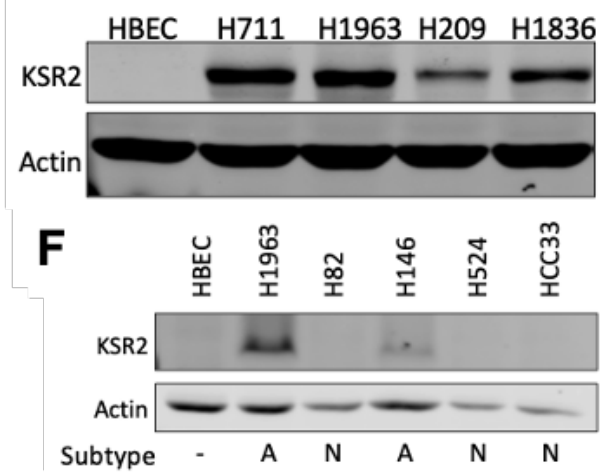


bioRxiv preprint doi: https://doi.org/10.1101/2022.02.11.480157; this version posted February 14, 2022. The copyright holder for this preprint (which was not certified by peer review) is the author/funder, who has granted bioRxiv a license to display the preprint in perpetuity. It is made available under aCC-BY 4.0 International license.

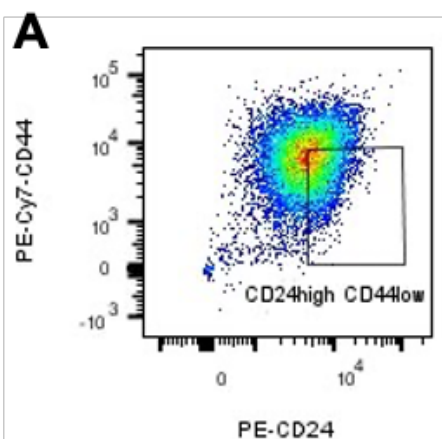

C

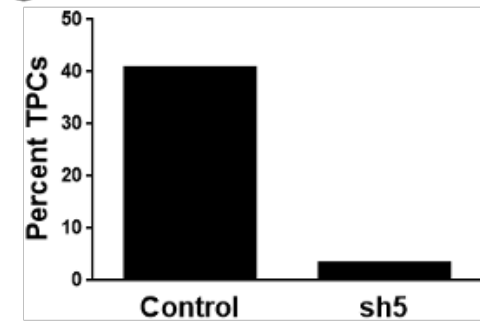

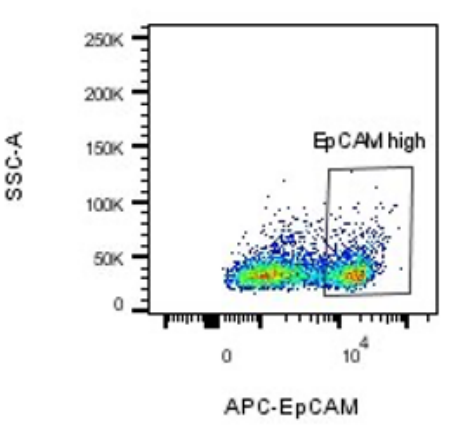

D

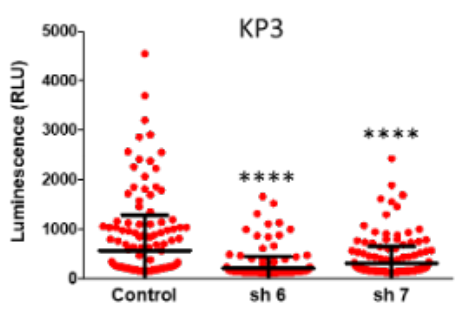

B

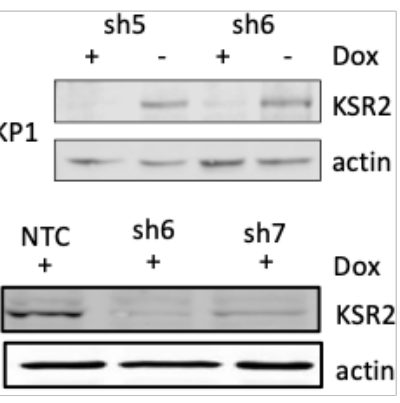

E

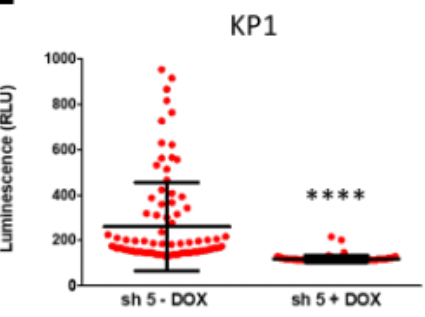

Fig. 2 
bioRxiv preprint dol: https://doi.org/10.1101/2022.02.11.480157; this version posted February 14, 2022. The copyright holder for this preprint (which was not certified by peer review) is the author/funder, who has granted bioRxiv a license to display the preprint in perpetuity. It is made available under aCC-BY 4.0 International license.

A

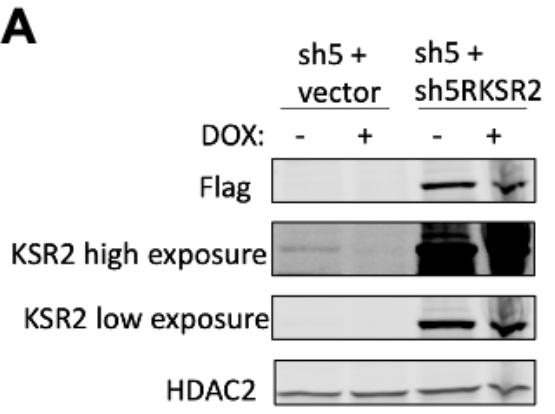

C $\mathrm{H} 209 \mathrm{sh} 5$

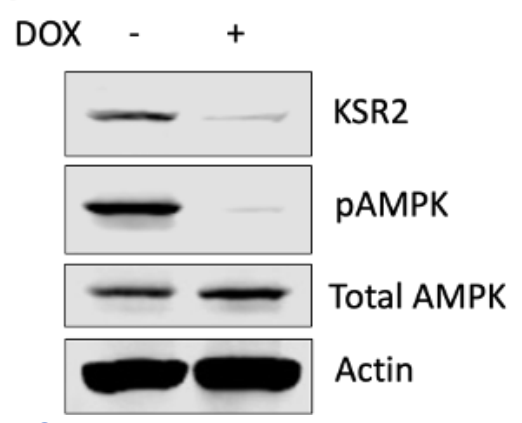

KP1 Rescue

B

ns

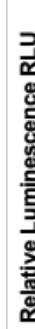

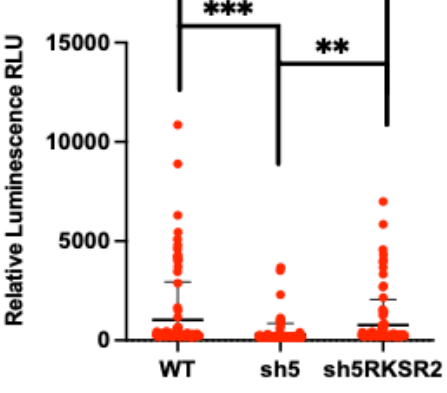

D

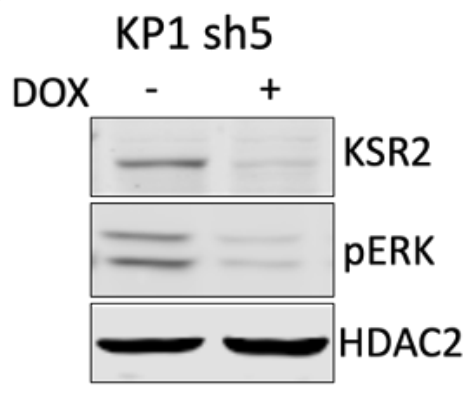

Fig. 3 
bioRxiv preprint doi: https://doi.org/10.1101/2022.02.11.480157; this version posted February 14,2022 . The copyright holder for this preprint (which was not certified by peer review) is the author/funder, who has granted bioRxiv a license to display the preprint in perpetuity. It is made available under aCC-BY 4.0 International license.

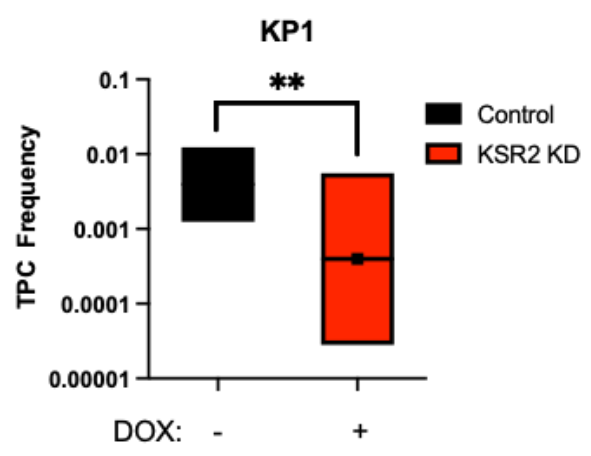

Table 1. ELDA KP1 cells \pm KSR2

Cells Mice Tumor Group

$\begin{array}{llll}10 & 3 & 0 & \text { control }\end{array}$

$\begin{array}{llll}50 & 3 & 1 & \text { control }\end{array}$

$\begin{array}{llll}100 & 3 & 2 & \text { control }\end{array}$

$\begin{array}{llll}200 & 3 & 3 & \text { control }\end{array}$

$\begin{array}{llll}500 & 3 & 1 & \text { control }\end{array}$

$\begin{array}{llll}10 & 3 & 0 & \text { dox }\end{array}$

$\begin{array}{llll}50 & 3 & 0 & \text { dox }\end{array}$

$\begin{array}{llll}100 & 3 & 1 & \text { dox }\end{array}$

$\begin{array}{llll}200 & 3 & 0 & \text { dox }\end{array}$

$500 \quad 3 \quad 0 \quad$ dox

Group TPC

Dox 2530

control 255

Chisq P value

$\begin{array}{ll}7.28 & 0.00698\end{array}$

Fig. 4 
bioRxiv preprint doi: https://doi.org/10.1101/2022.02.11.480157; this version posted February 14,2022 . The copyright holder for this preprint (which was not certified by peer review) is the author/funder, who has granted bioRxiv a license to display the preprint in perpetuity. It is made available under aCC-BY 4.0 International license.

Key Resources

\begin{tabular}{|c|c|c|c|c|}
\hline $\begin{array}{l}\text { Reagent } \\
\text { type } \\
\text { (species) or } \\
\text { resource }\end{array}$ & Designation & $\begin{array}{l}\text { Source or } \\
\text { reference }\end{array}$ & Identifiers & Additional information \\
\hline $\begin{array}{l}\text { Cell line } \\
\text { (Mus } \\
\text { musculus) }\end{array}$ & $\begin{array}{l}\text { Small-cell lung } \\
\text { carcinoma }\end{array}$ & $\begin{array}{l}\text { Obtained from Julien } \\
\text { Sage (Stanford } \\
\text { University) }\end{array}$ & KP1 & \\
\hline $\begin{array}{l}\text { Cell line } \\
\text { (Mus } \\
\text { musculus) }\end{array}$ & $\begin{array}{l}\text { Small-cell lung } \\
\text { carcinoma }\end{array}$ & $\begin{array}{l}\text { Obtained from Julien } \\
\text { Sage (Stanford } \\
\text { University) }\end{array}$ & KP3 & \\
\hline $\begin{array}{l}\text { Cell line } \\
\text { (Homo } \\
\text { sapiens) }\end{array}$ & $\begin{array}{l}\text { Small-cell lung } \\
\text { carcinoma }\end{array}$ & $\begin{array}{l}\text { Obtained from John } \\
\text { Minna (UT } \\
\text { Southwestern) }\end{array}$ & $\mathrm{H} 209$ & \\
\hline $\begin{array}{l}\text { Cell line } \\
\text { (Homo } \\
\text { sapiens) }\end{array}$ & $\begin{array}{l}\text { Small-cell lung } \\
\text { carcinoma }\end{array}$ & $\begin{array}{l}\text { Obtained from John } \\
\text { Minna (UT } \\
\text { Southwestern) }\end{array}$ & $\mathrm{H} 1963$ & \\
\hline $\begin{array}{l}\text { Transfected } \\
\text { construct }\end{array}$ & $\begin{array}{l}\text { piSMART } \\
\text { hEF1a/TurboGFP- } \\
\text { KSR2 shRNA } 5\end{array}$ & Dharmacon & $\begin{array}{l}\text { Cat\# } \\
\text { V3SH11252 } \\
-225640245\end{array}$ & GGAGCAAATCCCACGAGTT \\
\hline $\begin{array}{l}\text { Transfected } \\
\text { construct }\end{array}$ & $\begin{array}{l}\text { piSMART } \\
\text { hEF1a/TurboGFP- } \\
\text { KSR2 shRNA } 6\end{array}$ & Dharmacon & $\begin{array}{l}\text { Ca\#\# } \\
\text { V3SH11252 } \\
-227968197 \\
\end{array}$ & GCACATCAGTCAGACGCTC \\
\hline $\begin{array}{l}\text { Transfected } \\
\text { construct }\end{array}$ & $\begin{array}{l}\text { piSMART } \\
\text { hEF1a/TurboGFP- } \\
\text { KSR2 shRNA } 7\end{array}$ & Dharmacon & $\begin{array}{l}\text { Cat\# } \\
\text { V3SH11252 } \\
-228320208\end{array}$ & CCATCAAGCACAGGTTTTC \\
\hline $\begin{array}{l}\text { Recombinant } \\
\text { DNA reagent }\end{array}$ & sh5RKSR2 & This paper & $\begin{array}{l}\text { MSCV } \\
\text { KSR2 IRES } \\
\text { YFP }\end{array}$ & $\begin{array}{l}\text { QuikChange Lightning } \\
\text { Mutagenesis: Forward 5' } \\
\text { CGCTGCACAGGAGTAAGT } \\
\text { CCCAGTAATTCCAGCTCGG } \\
\text { G 3' } \\
\text { Reverse } \\
\text { 5'CCCGAGCGTGAATTCAT } \\
\text { GGGACTTACTCCTGTGCAG } \\
\text { CG 3' }\end{array}$ \\
\hline $\begin{array}{l}\text { Sequence } \\
\text { based } \\
\text { reagent }\end{array}$ & Ksr2 (PCR primer) & $(\text { Guo et al. 2017) })^{42}$ & & $\begin{array}{l}\text { Forward primer 5'- } \\
\text { TGGATGTCCGAAAGGAAGT } \\
\text { C-3' } \\
\text { Reverse primer 5'- } \\
\text { CTTCTCCACGGTCTCACAC } \\
\text { A-3' }\end{array}$ \\
\hline $\begin{array}{l}\text { Sequence } \\
\text { based } \\
\text { reagent }\end{array}$ & Crgp (PCR primer) & & & \\
\hline $\begin{array}{l}\text { Sequence } \\
\text { based } \\
\text { reagent }\end{array}$ & Chga (PCR primer) & & & \\
\hline $\begin{array}{l}\text { Sequence } \\
\text { based } \\
\text { reagent }\end{array}$ & Syp (PCR primer) & & & \\
\hline $\begin{array}{l}\text { Sequence } \\
\text { based } \\
\text { reagent }\end{array}$ & Spc (PCR primer) & & & \\
\hline
\end{tabular}


bioRxiv preprint doi: https://doi.org/10.1101/2022.02.11.480157; this version posted February $14,2022$. The copyright holder for this preprint (which was not certified by peer review) is the author/funder, who has granted bioRxiv a license to display the preprint in perpetuity. It is made available under aCC-BY 4.0 International license.

\begin{tabular}{|l|l|l|l|l|}
\hline Antibody & $\begin{array}{l}\text { Anti-B actin, mouse } \\
\text { monoclonal }\end{array}$ & Santa Cruz & Cat\# 47778 & WB 1:1000 \\
\hline Antibody & $\begin{array}{l}\text { Anti-KSR2 (MO8), } \\
\text { mouse monoclonal }\end{array}$ & Abnova & $\begin{array}{l}\text { Cat\# } \\
\text { H00283455- } \\
\text { M08 }\end{array}$ & WB 1:1000 \\
\hline Antibody & $\begin{array}{l}\text { Phospho-p44/42 } \\
\text { MAPK (Erk1/2) } \\
\text { (Thr202/Tyr204) } \\
\text { (E10), mouse } \\
\text { monoclonal }\end{array}$ & Cell Signaling & Cat\# 9106 & WB 1:1000 \\
\hline Antibody & $\begin{array}{l}\text { Anti-phospho- } \\
\text { AMPKa(Thr172)(40H } \\
\text { 9), rabbit monoclonal }\end{array}$ & Cell Signaling & Cat\# 2535 & WB: 1:1000 \\
\hline Antibody & $\begin{array}{l}\text { Anti-AMPKa, rabbit } \\
\text { polyclonal }\end{array}$ & Cell Signaling & Cat\# 2532 & WB 1:1000 \\
\hline Antibody & $\begin{array}{l}\text { Anti-Flag (M2), } \\
\text { mouse monoclonal }\end{array}$ & Sigma & Cat\# F3165 & WB 1:1000 \\
\hline Antibody & $\begin{array}{l}\text { Anti-HDAC2 (Y461), } \\
\text { rabbit monoclonal }\end{array}$ & Abcam & $\begin{array}{l}\text { Cat\# } \\
\text { ab32117 }\end{array}$ & WB: 1:1200 \\
\hline Antibody & $\begin{array}{l}\text { APC anti-mouse } \\
\text { CD326 (EpCAM), } \\
\text { mouse monclonal }\end{array}$ & Biolegend & $\begin{array}{l}\text { Cat\# } \\
118213\end{array}$ & FACS: 1:100 \\
\hline Antibody & $\begin{array}{l}\text { PE anti-mouse } \\
\text { CD24, mouse } \\
\text { monoclonal }\end{array}$ & Biolegend & $\begin{array}{l}\text { Cat\# } \\
101807\end{array}$ & FACS: 1:400 \\
\hline Antibody & $\begin{array}{l}\text { PE Cyanine7 anti- } \\
\text { mouse/human CD44, } \\
\text { mouse monoclonal }\end{array}$ & Biolegend & $\begin{array}{l}\text { Cat\# } \\
103029\end{array}$ & FACS: 1:300 \\
\hline $\begin{array}{l}\text { Nuclear } \\
\text { Stain }\end{array}$ & $\begin{array}{l}\text { DAPI (4',6-Diamidino- } \\
\text { 2-Phenylindole, } \\
\text { Dilactate) }\end{array}$ & Biolegend & $\begin{array}{l}\text { Cat\# } \\
422801\end{array}$ & FACS: 3 uM \\
\hline
\end{tabular}

\section{Acknowledgements}

The authors thank the UNMC Flow Cytometry Research Facility for help isolating SCLC TPCs.

We declare no conflicts of interest.

\section{Funding Information}

This work was supported by the Cancer and Smoking Disease Research Program (NE DHHS - LB 506), and R21CA256638.

The funders had no role in the study design, data collection and interpretation, or the decision to submit the work for publication. 